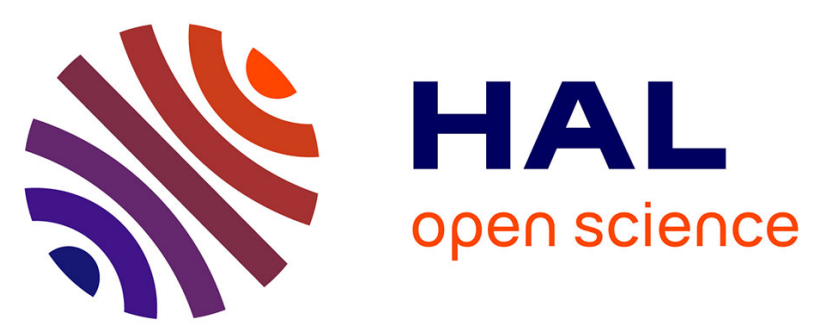

\title{
Copper Catalyst Activation Driven by Photoinduced Electron Transfer: A Prototype Photolatent Click Catalyst
}

Lydie Harmand, Sarah Cadet, Brice Kauffmann, Luca Scarpantonio, Pinar Batat, Gediminas Jonusauskas, Nathan Mcclenaghan, Dominique

Lastécouères, Jean-Marc Vincent

\section{To cite this version:}

Lydie Harmand, Sarah Cadet, Brice Kauffmann, Luca Scarpantonio, Pinar Batat, et al.. Copper Catalyst Activation Driven by Photoinduced Electron Transfer: A Prototype Photolatent Click Catalyst. Angewandte Chemie International Edition, 2012, 51 (29), pp.7137-7141. 10.1002/anie.201203014. hal-00731301

\section{HAL Id: hal-00731301 \\ https://hal.science/hal-00731301}

Submitted on 30 Aug 2018

HAL is a multi-disciplinary open access archive for the deposit and dissemination of scientific research documents, whether they are published or not. The documents may come from teaching and research institutions in France or abroad, or from public or private research centers.
L'archive ouverte pluridisciplinaire HAL, est destinée au dépôt et à la diffusion de documents scientifiques de niveau recherche, publiés ou non, émanant des établissements d'enseignement et de recherche français ou étrangers, des laboratoires publics ou privés.

\section{(1)(1) $\$(0)$}

Distributed under a Creative Commons Attribution - NonCommercial - ShareAlikel 4.0 


\title{
Copper Catalyst Activation Driven by Photoinduced Electron Transfer: A Prototype Photolatent Click Catalyst**
}

\author{
Lydie Harmand, Sarah Cadet, Brice Kauffmann, Luca Scarpantonio, Pinar Batat, \\ Gediminas Jonusauskas, Nathan D. McClenaghan, Dominique Lastécouères, and
} Jean-Marc Vincent*

The development of catalysts with light controlled activity is a challenging area of current research, with a strong potential for development. ${ }^{[1]}$ Considering transition metal catalysts, the generation of a highly active catalytic species on demand by light irradiation of an inactive precatalyst presents several key benefits: 1) metal species that are stable for handling under ambient conditions; 2) switching on catalysis at a given time and place; 3 ) tuning the onset of the generated active catalyst by controlling the photoactivation process, which would be valuable for highly exothermic reactions conducted on a large scale. To date, most examples of photocontrolled transition metal catalysts are the so called photocaged catalysts, which rely on the photodissociation or photodecomposition of ligands in coordinatively saturated metal complexes to generate vacant active sites. ${ }^{[1,2]}$ Inoue and co workers reported a rare example of a photoswitchable catalyst based on the use of a bulky photoisomerizable styryl pyridine ligand which, in its $Z$ form, activates an aluminium porphyrin catalyst through efficient coordination to the metal center. ${ }^{[3]}$ Photoinduced electron transfer to a metal cation might represent a valuable strategy to switch on the activity of metal based catalysts that are inactive in their high valent oxidized form, but active in their low valent reduced form. This oxidation state dependent activity is typically observed for the copper(I) catalyzed alkyne azide cycloaddition $(\mathrm{CuAAC})$ click reaction, ${ }^{[4]}$ a major reaction currently exploited in all fields of the chemical sciences. ${ }^{[5,6]}$ Within the last ten years a large number of catalysts have been developed for this reaction. ${ }^{[7]}$ Their common feature is that copper(I) has to be generated, the reaction proceeding first through the formation of a copper(I) acetylide, followed by cycloaddition with a copper(I) bound azide to generate a copper(II)

[*] L. Harmand, S. Cadet, Dr. L. Scarpantonio, Dr. N. D. McClenaghan Dr. D. Lastécouères, Dr. J. M. Vincent

Université Bordeaux CNRS UMR 5255

351 Crs de la Libération, 33405 Talence (France)

E mail: jm.vincent@ism.ubordeaux1.fr

Dr. P. Batat, Dr. G. Jonusauskas

Université Bordeaux CNRS UMR 5798 (France)

Dr. B. Kauffmann

European Institute of Chemistry and Biology, Pessac (France)

[**] The University of Bordeaux 1, the CNRS, the Région Aquitaine, and the European Research Council (FP7/2008 2013, ERC grant agree ment no. 208702) are gratefully acknowledged for their financial support. triazole, which is released by protonation. Among all the catalysts described so far, the only reported latent catalyst is the thermally activated $[(\mathrm{NHC}) \mathrm{CuCl}]$ complex $(\mathrm{NHC}=$ $\mathrm{N}$ heterocyclic carbene) developed by Nolan and co work ers. ${ }^{[8]}$ This complex is inactive under ambient conditions at room temperature (DMSO is used as solvent) but only becomes active if the temperature is raised to $60^{\circ} \mathrm{C}$ and water is added to the reaction mixture.

Chow and Buono Core discovered that certain aromatic ketones, benzophenones in particular, could sensitize the photoreduction of transition metal $\mathrm{ML}_{2}$ complexes such as $\left[\mathrm{Cu}(\mathrm{acac})_{2}\right] \quad(\mathrm{acac}=$ acetylacetonate $),{ }^{[9]}\left[\mathrm{Ni}(\mathrm{acac})_{2}\right],{ }^{[10]}$ or $\left[\mathrm{Cu}(\mathrm{Bp})_{2}\right] \quad(\mathrm{Bp}=\operatorname{dihydrobis}(1$ pyrazolyl)borate $)$ in hydro gen donating solvents. ${ }^{[11]}$ Extensive studies of the sensitized photochemistry showed that the photoreduction involves quenching of the triplet aromatic ketone, most likely by a charge transfer complex intermediate, which performs a monoelectronic oxidation of the ligand (L) to generate a ligand centered radical that abstracts a $\mathrm{H}$ atom from the solvent $\left(\mathrm{RCH}_{2} \mathrm{OH}\right)$. Overall the process generates the reduced complex $\mathrm{ML}$, the protonated ligand $\mathrm{L}-\mathrm{H}$, and an $\alpha$ hydroxy radical $\mathrm{R} \cdot \mathrm{CHOH}$.

Herein, we report the synthesis, characterization, prelimi nary photochemical studies, and catalytic activity of the $\left[\mathrm{Cu}\left(t \mathrm{BuBz}_{3}\right.\right.$ tren $)$ ketoprofenate $]$ ketoprofenate complex 1 (Figure 1). This species, which possesses a benzophenone like chromophore, is the first example of a photolatent click catalyst.

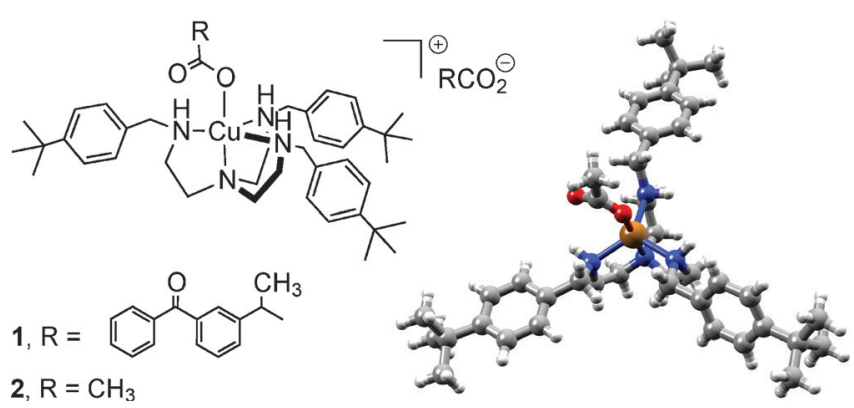

Figure 1. Structural formulas of complexes 1 and 2 (left) and molecular structure of the $\left[\mathrm{Cu}(t \mathrm{BuBz} \text { tren }) \mathrm{CH}_{3} \mathrm{CO}_{2}\right]^{+}$cation (right).

Precatalyst 1 was designed to be easily prepared while possessing two key structural/functional features: 1) A tetra dentate tren derived ligand $(\operatorname{tren}=\operatorname{tris}(2$ aminoethyl $)$ amine $)$, 
which should favor the stabilization of the $\mathrm{Cu}^{\mathrm{I}}$ reduced species, thus preventing the formation of colloidal $\mathrm{Cu}^{0}$, which may occur during the photoreduction process. Moreover we, ${ }^{[12]}$ and others ${ }^{[13]}$ have previously shown that the cop per(I) tren complexes are excellent click catalysts. 2) A ketoprofenate ligating counter anion as a photosensitizing group. Ketoprofen ( 2 ( 3 benzoylphenyl) propionic acid) is a well known, commercially available non steroidal anti inflammatory drug containing a benzophenone chromophore and a carboxylic acid group.

The $t \mathrm{BuBz}_{3}$ tren ligand $(\mathrm{Bz}=$ benzyl $)$ was prepared in $40 \%$ yield of isolated product through a reductive amination reaction (see the Supporting Information for details). The copper(II) complex $\quad\left[\mathrm{Cu}\left(t \mathrm{BuBz}_{3}\right.\right.$ tren $)$ ketoprofenate $]$ ketoprofenate (1) was isolated as a blue powder in $90 \%$ yield by reacting the $t \mathrm{BuBz}_{3}$ tren ligand with $\mathrm{CuOTf}_{2}(\mathrm{OTf}=$ trifluoromethanesulfonate) and the sodium salt of ketoprofen in methanol. Complex 1 was characterized by UV Vis and FT IR spectroscopy, elemental analysis, and ESI MS. In particular, the ESI MS spectrum (given in the Supporting Information) shows a major peak $(100 \%)$ at $\mathrm{m} / z=900.49$, which is assigned to the $\left[\mathrm{Cu}\left(t \mathrm{BuBz}_{3} \text { tren }\right) \text { ketoprofenate }\right]^{+}$ cation, suggesting that one ketoprofenate is bound to the copper(II) ion, as represented in Figure 1. This is further supported by single crystal $\mathrm{X}$ ray diffraction studies of the structural analogue $\left[\mathrm{Cu}(t \mathrm{BuBz}\right.$ tren $\left.) \mathrm{CH}_{3} \mathrm{CO}_{2}\right]\left(\mathrm{CH}_{3} \mathrm{CO}_{2}\right)$ (2) ${ }^{[23]}$ which reveal a copper(II) ion in a distorted trigonal bipyramidal geometry with an acetate occupying the axial coordination site in a syn monodentate mode (Figure 1). As with complex 1, the ESI MS spectrum of $\mathbf{2}$ (given in the Supporting Information) shows an intense peak at $\mathrm{m} / \mathrm{z}=$ $706.42(100 \%)$, which is attributed to the $[\mathrm{Cu}(t$ $\mathrm{BuBz}_{3}$ tren $\left.) \mathrm{CH}_{3} \mathrm{CO}_{2}\right]^{+}$cation.

Complex $\mathbf{1}$ is fully soluble in most organic solvents, in particular alcohols such as $\mathrm{MeOH}$, which seemed to be an appealing solvent for the photoreduction process. ${ }^{[9}{ }^{11]}$ More over, as $\mathrm{MeOH}$ is considered a green solvent, ${ }^{[14]}$ it is a good solvent candidate for click reactions. The copper(II) to copper(I) photoreduction process was first evidenced by following the disappearance of the characteristic visible absorption band of $\mathbf{1}$, which is centered at $828 \mathrm{~nm}$ and arises

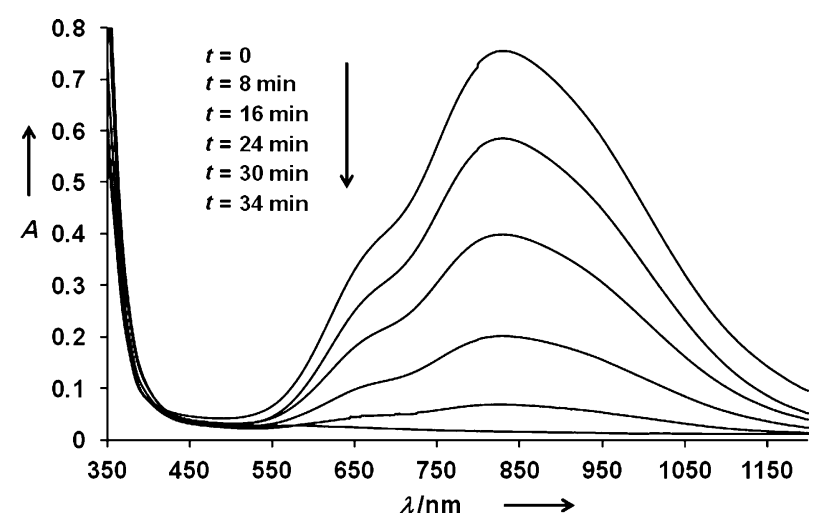

Figure 2. Evolution of the visible absorption spectrum of a $\mathrm{MeOH}$ solution of 1 ( $3 \mathrm{~mL}, 1.85 \mathrm{~mm}$, deoxygenated by freeze pump thaw cycles, sealed cell) upon irradiation at $365 \mathrm{~nm}$. from a d d transition. As shown in Figure 2, when a deoxy genated blue methanolic solution of $\mathbf{1}(1.9 \mathrm{~mm})$ is irradiated at $365 \mathrm{~nm}$, the complete disappearance of the $828 \mathrm{~nm}$ absorption band is observed within approximately $30 \mathrm{~min}$ and a limpid colorless solution, consistent with the formation of a cuprous $\left[\mathrm{Cu}\left(t \mathrm{BuBz} z_{3} \text { tren }\right)\right]^{+}$cationic species, is observed.

The quantum yield for this copper reduction process $\left(\Phi_{\text {red }}\right)$ in methanol was determined to be relatively high at 0.17 , in comparison with a ferrioxylate salt actinometer irradiating at $365 \mathrm{~nm}$. This assumes that the photoprocess is the only factor responsible for the changing absorption. ${ }^{[15]}$

Direct evidence for the clean formation of a cuprous $\left[\mathrm{Cu}\left(t \mathrm{BuBz}_{3} \text { tren }\right)\right]^{+}$cationic species comes from ${ }^{1} \mathrm{H} \mathrm{NMR}$ experiments. The ${ }^{1} \mathrm{H}$ NMR spectrum of $\mathbf{1}$ is characteristic of a paramagnetic complex $(S=1 / 2)$, affording very broad peaks for the aromatic protons of the ketoprofenate anions and tren ligand (between 7.30 and $8.80 \mathrm{ppm}$ ), and the methyl protons of the tert butyl groups (at $1.49 \mathrm{ppm}$ ), even if they are quite far from the copper(II) ion (Figure 3). Neither the methylenic

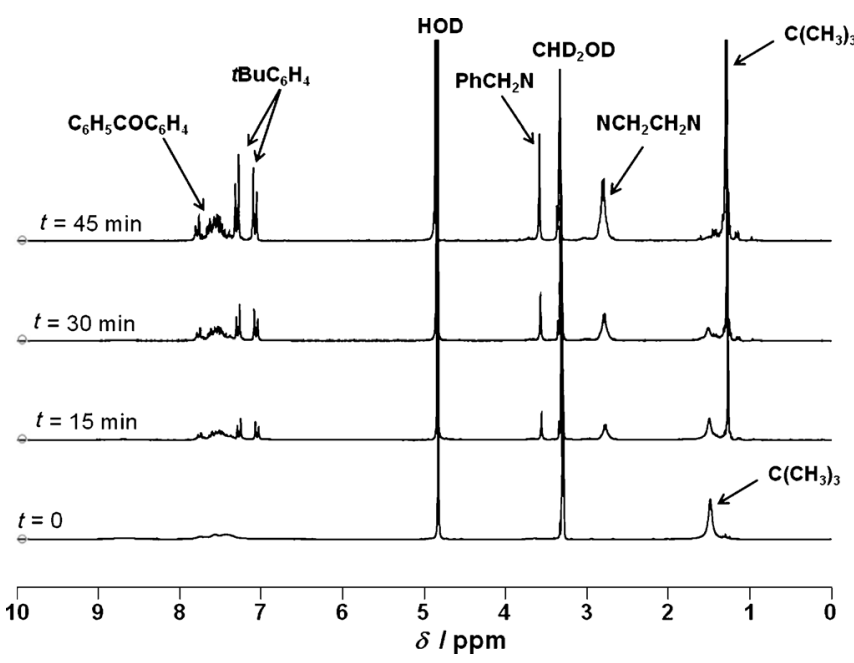

Figure 3. Evolution of the ${ }^{1} \mathrm{H} N M R$ spectrum of a $\mathrm{CD}_{3} \mathrm{OD}$ solution of $1(0.5 \mathrm{~mL}, 5 \mathrm{~mm}$, deoxygenated by freeze pump thaw cycles, sealed tube) upon irradiation of the NMR tube at $365 \mathrm{~nm}$.

protons of the benzylic positions and the tren scaffold, nor the aliphatic protons of the ketoprofenate ions are observed. Upon irradiation of the NMR tube, a fast and dramatic change in the spectrum is observed, with the complete disappearance of the broad resonances of $\mathbf{1}$ within ca. 45 min while, concomitantly, sharp resonances assigned to the diamagnetic $(S=0)$ cuprous $\left[\mathrm{Cu}\left(t \mathrm{BuBz}_{3} \text { tren }\right)\right]^{+}$cation appear. In particular, all of the proton resonances of the $t \mathrm{BuBz}_{3}$ tren ligand of the cuprous cation can be clearly identified at 7.28 and $7.06 \mathrm{ppm}$ for the phenyl rings, and at $3.56,2.78$, and $1.27 \mathrm{ppm}$ for the benzylic $\mathrm{CH}_{2}, \mathrm{CH}_{2} \mathrm{~N}$, and $t \mathrm{Bu}$ groups, respectively. The complicated resonance pattern observed for the aromatic protons of ketoprofen is ascribed to the coexistence, after reduction, of several types of ketoprofen species: one ketoprofenate interacting with the copper(I) cation, and one equivalent of ketoprofen (acid form) with respect to copper released during the reduction 
process (see the photochemical study below and the proposed mechanism).

To gain insight into the photoreduction mechanism, preliminary transient absorption studies were performed in degassed $\mathrm{MeOH}$ solution. On irradiating 1 at $355 \mathrm{~nm}$, a positive transient absorption band is observed in the visible region at $530 \mathrm{~nm}$ (Supporting Information, Figure S4), which is characteristic of the triplet ketoprofen, the formation of which is a key primary step in the photoinduced sequence of events. $^{[16,17]}$ Although a similar signature is noted for the ketoprofen alone (acid form), it is clear that the decay kinetics are very different (Supporting Information, Figure S5). The kinetics of the deexcitation of the ketoprofen (acid form) exhibit a typical, relatively slow decay $(\tau=370 \mathrm{~ns})$ of the visible transient absorption band, ${ }^{[16,17]}$ which normally involves reaction with methanol, a rather efficient hydrogen donor. ${ }^{[17]}$ For complex 1, the decay of the absorption band has a time constant of 9.4 ns. Thus, the long decay time constant is dramatically reduced in the presence of the copper complex. As in previous reports by Chow, Buono Core, and co workers on the related benzophenone sensitized photoreduction of $\left[\mathrm{Ni}(\mathrm{acac})_{2}\right],\left[\mathrm{Cu}(\mathrm{acac})_{2}\right]$, or $\left[\mathrm{Cu}(\mathrm{Bp})_{2}\right]$ complexes, ${ }^{[9}{ }^{11]}$ the observed triplet decay in $\mathbf{1}$ is thus much faster $(k=1.0 \times$ $10^{8} \mathrm{~s}^{-1}$ ) than the triplet decay measured in $\mathrm{MeOH}$ for the acid form of ketoprofen $\left(k=2.7 \times 10^{6} \mathrm{~s}^{-1}\right)$, which shows the intervention of a fast additional quenching pathway for this excited state in the presence of the copper complex. From these results, and by analogy with previous studies, a tentative mechanism for the reduction process is proposed, according to equations 14 . Irradiation of 1 produces the ketoprofen (ket) triplet [Eq. (1)] which can be quenched by electron

$$
[\operatorname{trenCu}(\mathrm{II}) \mathrm{ket}]^{+} \stackrel{h v}{\longrightarrow}\left[\operatorname{trenCu}(\mathrm{II}) \mathrm{ket}^{\star}\right]^{+}
$$

transfer from copper(II), see below, leading to a formal $\left[\operatorname{trenCu}{ }^{\text {III }} \mathrm{ket}^{-}\right]^{+}$intermediate, followed by a one electron oxidation of the ligand to generate $\left[\operatorname{tren}^{+} \mathrm{Cu}^{\mathrm{II}} \mathrm{ket}^{-}\right]^{+}$ [Eq. (2)]. The resulting ligand centered radical may then

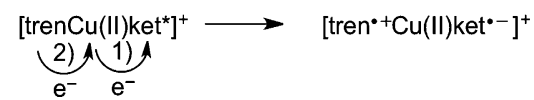

abstract an $\mathrm{H}$ atom from the $\mathrm{H}$ donating $\mathrm{MeOH}$ solvent [Eq. (3)]. A back electron transfer affords the copper(I)

$\left[\operatorname{tren}^{\cdot+} \mathrm{Cu}(\mathrm{II}) \mathrm{ket}^{\cdot-}\right]^{+}+\mathrm{CH}_{3} \mathrm{OH} \longrightarrow\left[\operatorname{trenCu}(\mathrm{II}) \mathrm{ket}^{\cdot-}\right]+{ }^{\cdot} \mathrm{CH}_{2} \mathrm{OH}+\mathrm{H}^{+}$

species and regenerates the ketoprofenate counteranion [Eq. (4)]. It is noteworthy that the photoinduced reduction

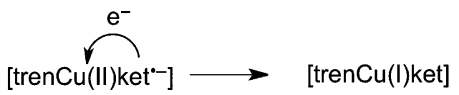

does not occur in $\mathbf{2}$ (where acetate replaces the ketoprofen), which shows the fundamental photostability of the inorganic moiety when irradiating at $365 \mathrm{~nm}$. Moreover, when the methanol solvent is replaced by dichloromethane, which is a poor $\mathrm{H}$ donating solvent, the reduction process is much less efficient as ca. $75 \%$ of $\mathbf{1}$ is reduced after $3 \mathrm{~h}$ irradiation
(Supporting Information, Figure S1). This is in agreement with a radical process, which necessitates $\mathrm{H}$ atom abstraction [Eq. (3)].

The driving force and hence the feasibility for the initial photoinduced electron transfer [PET; Eq. (2)] can be esti mated by considering the difference in potential for oxidation of the ligated $\mathrm{Cu}^{\mathrm{II}}$ center and the potential for reduction of the excited ketoprofen moiety. ${ }^{[18]}$ The reduction of ketoprofen at $-1.36 \mathrm{~V}$ (V vs. SCE; SCE = saturated calomel electrode) and the triplet energy of related benzophenones at $3.0 \mathrm{eV}$ have previously been determined. ${ }^{[19,20]}$ Cyclic voltammetry was performed in both methanol and in acetonitrile (wherein the reversibility of the redox processes at the copper center was improved, thus allowing half wave potential determination, see Figure S6 in the Supporting Information). A fully reversible wave attributed to the $\mathrm{Cu}^{\mathrm{I}} / \mathrm{Cu}^{\mathrm{II}}$ couple $(-0.34 \mathrm{~V}$ vs. SCE) as well as a quasi reversible wave corresponding to $\mathrm{Cu}^{\mathrm{II}} / \mathrm{Cu}^{\mathrm{III}}(+1.29 \mathrm{~V}$ vs. SCE$)$ were observed. The tren like ligand clearly plays an important role in facilitating these two one electron oxidation processes. The thermodynamic driving force $\left(\Delta G^{0}\right)$ for the PET process from $\mathrm{Cu}^{\mathrm{II}}$ to the ketoprofen triplet is ca. $-0.35 \mathrm{eV}$, showing it to be exothermic and favorable. Further studies will be conducted to confirm the proposed mechanism, in particular the intermediacy of a ligand centered radical, as unambiguously evidenced for the photoreduction of $\left[\mathrm{Cu}(\mathrm{acac})_{2}\right]$ and $\left[\mathrm{Ni}(\mathrm{acac})_{2}\right] .^{[9,10]}$

The latent behavior and click reactivity of $\mathbf{1}$ was probed with the reaction between the unprotected sugar $\beta$ D galac topyranosyl azide (3) and propargyl alcohol (4), both of which are soluble in methanol. Figure 4 shows the conversion profiles of click reactions run at room temperature in deoxygenated $\mathrm{CD}_{3} \mathrm{OD}$ (Ar purged) with $0.5 \mathrm{~mol} \% 1$ (reac tions followed by ${ }^{1} \mathrm{H}$ NMR spectroscopy, see Figure S2 in the Supporting Information). It is noteworthy that under ambient conditions $\mathbf{1}$ exhibits no residual background activity (Figure 4, $\bullet$ ), a crucial parameter when considering effective photoswitchable catalysts. Irradiating the NMR tube at

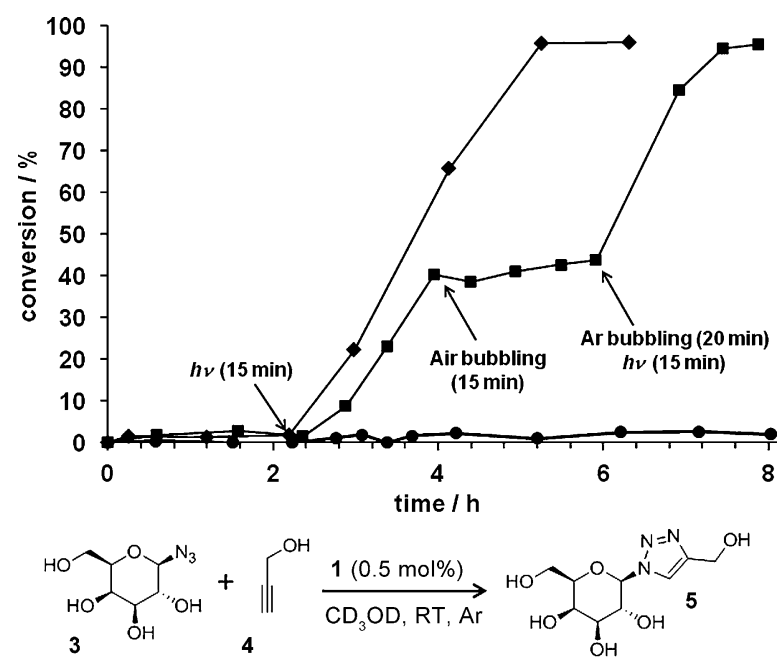

Figure 4. Reaction profiles of $\mathrm{CD}_{3} \mathrm{OD}$ solutions $(0.33 \mathrm{M}, 0.75 \mathrm{~mL})$ of 3 and 4 with 1 ( $0.5 \mathrm{~mol} \%)$ followed by ${ }^{1} \mathrm{H}$ NMR spectroscopy and applying external stimuli. 
$365 \mathrm{~nm}$ for $15 \mathrm{~min}$, for example, after a latency period of $2 \mathrm{~h}$, switches the catalysis on (Figure $4, \bullet$ ). The resulting copper(I) catalyst is highly reactive, affording an almost quantitative formation of the triazole 5 in ca. $3 \mathrm{~h}$.

Once started, the reaction can be stopped completely at any time by simply bubbling air through the reaction mixture, because of the almost instantaneous oxidation of the catalyst by molecular oxygen (Figure $4, \mathbf{a}$ ). Indeed, when exposed to air the solution immediately turned green, indicating that the photogenerated copper(I) complex is readily reoxidized by oxygen. Interestingly, the inhibition process is fully reversible. Bubbling Ar through the reaction mixture followed by $15 \mathrm{~min}$ irradiation restores the catalytic activity, with a reaction rate similar to that observed before oxygen inhibition (Figure 4). For comparison, conversions of $1025 \%$ were determined by ${ }^{1} \mathrm{H}$ NMR spectroscopy after $3 \mathrm{~h}$ reaction time using $0.5 \mathrm{~mol} \%$ of $\mathrm{CuSO}_{4}$ /sodium ascorbate, ${ }^{[4 \mathrm{a}]} \mathrm{CuPPh}_{3} \mathrm{CN}^{[21]}$ or $\mathrm{CuOAc}^{[22]}$ in solvents that provided the best activity for these catalysts in our hands: $\mathrm{D}_{2} \mathrm{O}$ for $\mathrm{CuSO}_{4}$ and $\mathrm{CuPPh}_{3} \mathrm{CN}$, and $\mathrm{CD}_{3} \mathrm{OD}$ for $\mathrm{CuOAc}$ ( $24 \mathrm{~h}$ reaction profiles are given in the Figure $\mathrm{S} 3$ of the Supporting Information).

Finally, click reactions were conducted for a range of alkynes with aromatic, aliphatic, electron withdrawing, or bulky substituents (round bottom flask, 20 min Ar bubbling, $30 \mathrm{~min}$ of irradiation). The catalyst loading was $0.5 \mathrm{~mol} \%$, except for the ethyl propiolate $(1 \mathrm{~mol} \%)$. The reactions were stopped at $>95 \%$ conversions (determined by ${ }^{1} \mathrm{H}$ NMR) at the times indicated in Figure 5. The pure triazoles $5 \mathbf{1 2}$ were

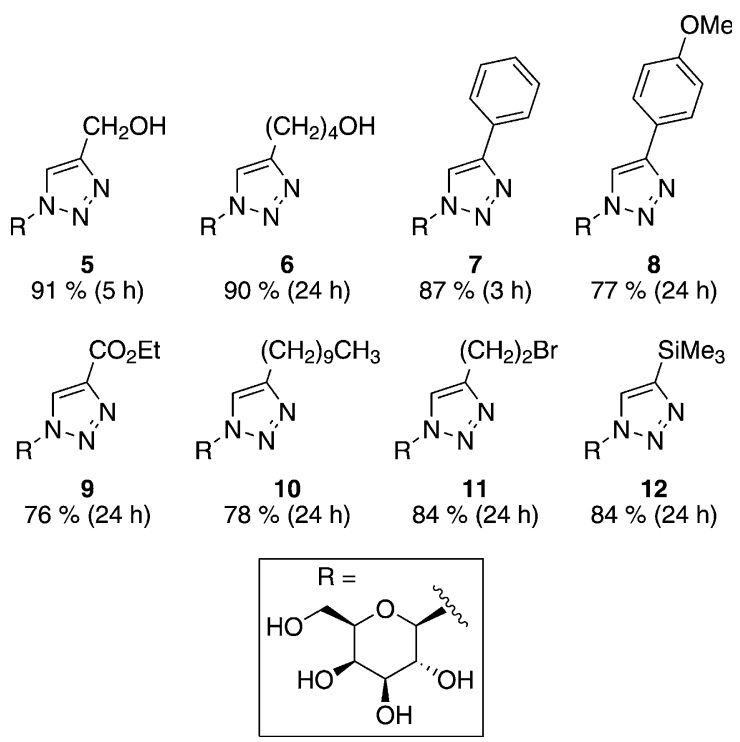

Figure 5. Structures and reaction yields for the triazoles 5 12. Reaction times are shown in parentheses.

isolated in $7691 \%$ yield without chromatography by simple precipitation upon addition of either diethyl ether or toluene.

In conclusion, by exploiting the benzophenone derived ketoprophenate counteranion, it is possible to efficiently photoreduce the copper(II) ion of air stable complex 1 to generate a highly reactive copper(I) tren click catalyst on demand. From a practical perspective, such photolatent catalysts should prove very useful. Indeed, copper(I) poly amino/imino complexes possessing accessible coordination sites are well known to be extremely reactive towards oxygen, thus complicating the preparation, handling, and storage of such compounds. Moreover, when conducting highly exo thermic reactions, which is the case with CuAAC, particularly on large scale and/or in high concentration, the use of a catalytic system that can be switched on upon irradiation and switched off by simply introducing air into the reaction medium, should be very attractive. The fact that the onset of the active species can be finely controlled depending on the irradiation time is an additional interesting feature for such applications. Finally, we believe that the reported photo induced reduction process could be extended, not only to other important copper(I) catalyzed reactions, but also to other transition metal catalyzed processes. Studies along these lines are currently in progress.

Keywords: click chemistry - copper - Huisgen cycloaddition . photocontrolled catalysts - photolatent catalysts

[1] For a recent review on photocontrolled catalysts, see: R. S. Stoll, S. Hecht, Angew. Chem. 2010, 122, 5176 5200; Angew. Chem. Int. Ed. 2010, 49, 50545075.

[2] For selected examples, see: a) B. K. Keitz, R. H. Grubbs, J. Am. Chem. Soc. 2009, 131, 2038 2039; b) D. Wang, K. Wurst, W. Knolle, U. Decker, L. Prager, S. Naumov, M. R. Buchmeiser, Angew. Chem. 2008, 120, 3311 3314; Angew. Chem. Int. Ed. 2008, 47, 3267 3270; c) L. Delaude, M. Szypa, A. Demonceau, A. F. Noels, Adv. Synth. Catal. 2002, 344, 749 756; d) A. Fürstner, L. Ackermann, Chem. Commun. 1999, 95 96; e) M. Picquet, C. Bruneau, P. H. Dixneuf, Chem. Commun. 1998, 2249 2250; f) A. Hafner, A. Mülhebach, P. A. van der Schaaf, Angew. Chem. 1997, 109, 2113 2116; Angew. Chem. Int. Ed. Engl. 1997, 36, 2121 2124; g) A. L. Prignano, W. C. Trogler, J. Am. Chem. Soc. 1987, 109, 3586 3595; h) J. C. Mitchener, M. S. Wrighton, J. Am. Chem. Soc. 1981, 103, 975977.

[3] H. Sugimoto, T. Kimura, S. Inoue, J. Am. Chem. Soc. 1999, 121, 23252326.

[4] a) V. V. Rostovtsev, L. G. Green, V. V. Fokin, K. B. Sharpless, Angew. Chem. 2002, 114, 2708 2711; Angew. Chem. Int. Ed. 2002, 41, 2596 2599; b) C. W. Tornøe, C. Christensen, M. Meldal, J. Org. Chem. 2002, 67, 30573064.

[5] See the themed issues: a) "Applications of click chemistry", guest Eds.: M. G. Finn, V. Fokin, Chem. Soc. Rev. 2010, 39, 1231 1405 ; b) "Click chemistry in polymer science", guest Ed.: W. H. Binder, Macromol. Rapid Commun. 2008, 29, 9431185.

[6] For selected reviews, see: a) M. Meldal, C. W. Tornøe, Chem. Rev. 2008, 108, 2952 3015; b) V. D. Bock, H. Hiemstra, J. H. van Maarseveen, Eur. J. Org. Chem. 2006, 51 68; c) L. Liang, D. Astruc, Coord. Chem. Rev. 2011, 255, 29332945.

[7] For a review focusing on copper(I) click catalysts, see: S. Díez González, Catal. Sci. Technol. 2011, 1, 166178.

[8] S. Díez González, E. D. Stevens, S. P. Nolan, Chem. Commun. 2008, 47474749.

[9] a) Y. L. Chow, G. E. Buono Core, Can. J. Chem. 1983, 61, 795 800; b) Y. L. Chow, G. E. Buono Core, Can. J. Chem. 1983, 61, 801808 ; c) Y. L. Chow, G. E. Buono Core, J. Am. Chem. Soc. 1982, 104, 3770 3771; d) Y. L. Chow, G. E. Buono Core, J. Am. Chem. Soc. 1986, 108, 12341239. 
[10] a) Y. L. Chow, G. E. Buono Core, C. W. B. Lee, J. C. Scaiano, J. Am. Chem. Soc. 1986, 108, 7620 7627; b) Y. L. Chow, G. E. Buono Core, J. Chem. Soc. Chem. Commun. 1985, 592594.

[11] a) G. E. Buono Core, A. H. Klahn, F. Aros, V. Astorga, Poly hedron 1996, 15, 363 366; b) G. E. Buono Core, A. H. Klahn, C. Bahamondes, F. Aros, M. Tejos, V. Astorga, Inorg. Chim. Acta 1997, 257, 241245 .

[12] a) N. Candelon, D. Lastécouères, A. Khadri Diallo, J. Ruiz Ar anzaes, D. Astruc, J. M. Vincent, Chem. Commun. 2008, 4143 b) L. Harmand, M. H. Lescure, N. Candelon, M. Duttine, D. Lastécouères, J. M. Vincent, Tetrahedron Lett. 2012, 53, 1417 1420.

[13] a) P. L. Golas, N. V. Tsarevsky, B. S. Sumerlin, K. Matyjaszewski, Macromolecules 2006, 39, 6451 6457; b) L. Liang, J. Ruiz, D. Astruc, Adv. Synth. Catal. 2011, 353, 34343450.

[14] C. Capello, U. Fischer, K. Hungerbühler, Green Chem. 2007, 9, 927934.

[15] M. Montalti, A. Credi, L. Prodi, M. T. Gandolfi in Handbook of Photochemistry, 3rd ed., CRC Press, New York, 2006, pp. 601 604.
[16] I. Carmichael, G. L. Hug, J. Phys. Chem. Ref. Data 1986, 15, 1 250.

[17] G. Cosa, L. J. Martinez, J. C. Scaiano, Phys. Chem. Chem. Phys. 1999, 1, 35333537.

[18] D. Rehm, A. Weller, Isr. J. Chem. 1970, 8, 259271.

[19] T. V. Popova, N. V. Aksenova, Russ. J. Coord. Chem. 2003, 29 , 743765.

[20] a) L. Amankwa, L. G. Chatten, Analyst 1984, 109, 57 60; b) D. W. Margerum, L. F. Wong, F. P. Bossu, K. L. Chellappa, J. J. Czarnecki, S. T. Kirksey, Jr., T. A. Neubecker in Bioinor ganic Chemistry II, Vol. 162, Advances in Chemistry Series, ACS, 1977, pp. 281303

[21] S. Lal, S. Díez González, J. Org. Chem. 2011, 76, 23672373.

[22] C. Shao, G. Cheng, D. Su, J. Xu, X. Wang, Y. Hu, Adv. Synth. Catal. 2010, 352, 15871592.

[23] CCDC 867283 (2) contains the supplementary crystallographic data for this paper. These data can be obtained free of charge from The Cambridge Crystallographic Data Centre via www. ccdc.cam.ac.uk/data request/cif. 